Draft letter to Addiction

\title{
Loss of materials and resources for addiction researchers: comment on Mitchell et al. (2012)
}

Dear Editor,

The Editorial in Addiction on 2 August by Mitchell et al [1] on the closure of addiction libraries highlights an issue that has been going on for a decade or more. It is only part of a wider phenomenon of equal interest to researchers in the addictions field, especially in respect of drugs.

The authors have rightly flagged up in respect of the UK the downsizing/closing of specialist addiction libraries such as those maintained by Alcohol Concern and DrugScope (formerly SCODA and ISDD). Not only were they unique repositories for published and 'grey' literature, they were also able to provide guidance and assistance to researchers trying to locate 'hard to find' publications. To a certain but limited extent, ELISAD and SALIS have been able to assist individual researchers, such as myself, in this respect. These and other networks are an invaluable source of knowledge and expertise which need support financially.

However, it is also important to remark on the downsizing/closure of libraries maintained by Government departments. In the UK context, some of these held unique collections of documents, as well as published books and statistical volumes, of relevance to historians of addictions policy and students of drug epidemiology. These Government departmental libraries, e.g. Home Office, Department of Health, and Office for National Statistics, have either totally disappeared or had the resources allocated to them severely reduced as a response to successive budgetary cuts.

For someone like myself, a former member of the Home Office Drugs \& Alcohol Research Unit, who worked on Home Office drug statistics between 1987 and 2002, with an interest in the history and evolution of addiction and substance use in the UK, the departmental library was well staffed with experienced librarians and held an extensive stock of official publications covering the UK Government's annual reports on drugs to the League of Nations and United Nations, historic volumes relating to the period of the "Opium Wars" and subsequent development of international narcotics controls, Home Office statistical bulletins, as well as books on various aspects of addiction, and unpublished documents and reports. However, in 2005, when the Headquarter s building moved from Queen Anne's Gate to its current location in Marsham Street the resources allocated to the library were reduced. As a result many of the items of interest relating to the evolution of addiction policies and drug epidemiology were disposed of. It is unfortunate that at the time, specialist addiction libraries such as that maintained by DrugScope were unable to take custody of these materials. One hopes that suitable homes were found for them, but the position is unclear. It is thus difficult to use such resources for research.

In respect of published statistics relating to drug epidemiology, the accessibility of Home Office publications on behalf of $\mathrm{H} \mathrm{M}$ Government to the League of Nations and United Nations is now probably limited to National Libraries such as the British Library and the UN library in Geneva. Personal visits have to be undertaken as such volumes are not available digitally. Although the Home Office Research Development \& Statistics Directorate (RDS) did have a complete set of statistical volumes covering drug statistics (including notifications to the Home Office Addicts Index [2], Drug Seizures \& Offences [3], and Drug-related Offences) prior to the move to Marsham Street. One fears that this collection may have been disposed of or otherwise overlooked during the move. Whilst the main statistical volumes, as well as research reports, are available on line at the archived RDS website

[http://webarchive.nationalarchives.gov.uk/20110218135832/http://rds.homeoffice.gov.uk/rds/index.ht $\mathrm{ml}]$ this site only covers the period from 1979. Furthermore, many of the area and supplementary tables' volumes are not available on line. Thus personal visits to the National libraries would be entailed if the information was needed by researchers.

One acknowledges the difficulties of resourcing libraries, depositories, and other sources of historic and contemporary materials on addictions, but there is a need to ensure that we know what still exists, where it is located, and how it can be accessed, and by whom, and the information made publically available. Similarly, the needs of future researchers and historians needs to be borne in 
mind when considering archiving or disposing of what might be considered ephemeral information (including datasets) but which in a decade or two might be vital for evaluating the success or otherwise of current policy decisions, and studying the epidemiology of substance use/addictions.

John Martin Corkery, BA Hons (Open) MSC MPhil AFHEA

Research Co-ordinator, School of Pharmacy, University of Hertfordshire, Hatfield, UK

Honorary Research Fellow, International Centre for Drug Policy, St George's University of London, UK

\section{Contact details}

John M Corkery, School of Pharmacy, University of Hertfordshire

College Lane Campus, Hatfield, Herts. UK AL10 9AB

Tele: +44 (0)1707 281053

i.corkery@herts.ac.uk

\section{Declaration of interest}

Former drugs researcher and statistician in the Home Office

Member of Health Archives \& Records Group

\section{Key words}

Addiction, library, epidemiology, policy, history, resources

\section{References}

1. Mitchell AL, Lacroix S, Weiner BS, Imholtz C, Goodair C. Collective amnesia: reversing the global epidemic of addiction library closures. Addiction. 2012 Aug;107(8):1367-1368. doi: 10.1111/j.13600443.2012.03813.x. Epub 2012 Jun 12. PubMed PMID: 22686458.

2. Corkery, J.M. (1997). Statistics of Drug Addicts notified to the Home Office, United Kingdom, 1996, Home Office Statistical Bulletin 22/97; Area Tables; Scotland Tables. 14 October 1997. London: Home Office Research and Statistics Directorate.

3. Corkery, J.M. (2002). Drug seizure and offender statistics, United Kingdom, 2000, Home Office Statistical Bulletin 4/02. Area Tables \& Supplementary Tables volumes. 17 May 2002. London: Home Office Research, Development and Statistics Directorate. 